\title{
Review on properties of aluminium metal matrix composites
}

Balasubramani SUBRAMANIAM, Vijay Rengaraj PURUSOTHAMAN, Sibi

Mayuran KARUPPUSAMY, Shree Hari GANESH, Raj Kumar MARKANDAN

DOI: $10.30464 /$ jmee.2020.4.1.57

Cite this article as:

Subramaniam B., et al. Review on properties of aluminium metal matrix composites. Journal of Mechanical and Energy Engineering, Vol. 4(44), No. 1, 2020, pp. 57-66.

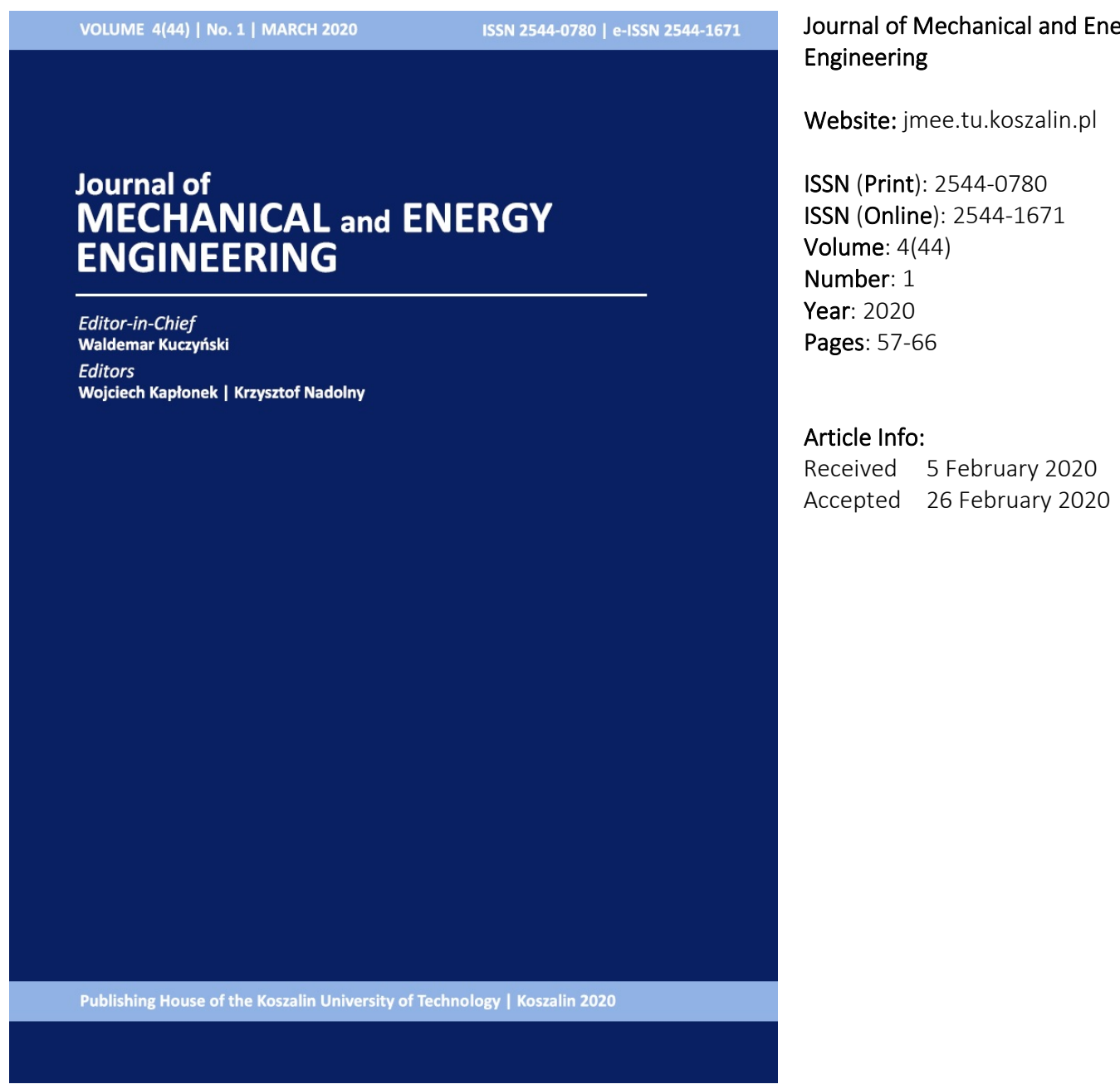

Open Access

This article is distributed under the terms of the Creative Commons Attribution 4.0 (CC BY 4.0) International License (http://creativecommons.org/licenses/by/4.0/), which permits unrestricted use, distribution, and reproduction in any medium, provided you give appropriate credit to the original author(s) and the source, provide a link to the Creative Commons license, and indicate if changes were made. 


\title{
REVIEW ON PROPERTIES OF ALUMINIUM METAL MATRIX COMPOSITES
}

\author{
Balasubramani SUBRAMANIAM ${ }^{1 *}$, Vijay Rengaraj PURUSOTHAMAN ${ }^{2}$, \\ Sibi Mayuran KARUPPUSAMY², Shree Hari GANESH², Raj Kumar MARKANDAN ${ }^{2}$ \\ 1* Faculty of Mechanical Engineering, Department of Production Engineering, Sri Eshwar College of Engineering, \\ Coimbatore - 641202, Tamilnadu, India, e-mail: balumecadcam@gmail.com, telephone: 04259-200 300 \\ ${ }^{2}$ Department of Mechanical Engineering, Sri Eshwar College of Engineering, Coimbatore-641202, India
}

(Received 5 February 2020, Accepted 26 February 2020)

\begin{abstract}
Nowadays, the global industries producing mechanical components are moving towards the usage of composites to reduce weight at the same time without compromising with characteristics of the material being used. This new combination of material provides specific desired properties when combined with various reinforcement materials like $\mathrm{SiC}, \mathrm{B}_{4} \mathrm{C}, \mathrm{Al}_{2} \mathrm{O}_{3}$, $\mathrm{MgO}$ etc., It is widely used in various industries like aerospace, automobile and marine industries. This property specific tailorable metal matrix composite with Al7075 as the base material can be fabricated using various techniques such as stir casting, high end ball milling, ultrasonic assisted casting, powder metallurgy, squeeze casting friction stir casting etc., out of which stir casting method is preferred by many researchers as stir casting method is seen to provide better distribution of reinforcement particles throughout the metal matrix. It is evident from the research of various authors that when the base material Al7075 is reinforced with the above-mentioned ceramic, it is found that there is a decrease in density and increase in hardness, compressive strength and wear resistance. Here, both physical and mechanical behaviour of aluminium reinforced composites with the effect of the particle size changes, effects after reinforcement and other processing and fabrication methods have been discussed.
\end{abstract}

Keywords: aluminium, metal matrix composites, reinforcement, fabrication techniques, properties of metal matrix composites

\section{INTRODUCTION}

The industries are shifting rapidly towards using composites due to their enhanced properties, lower cost, eco-friendly characteristics and lighter weight comparatively there-by increasing its desirability to replace the conventional ones [7]. The different composites are obtained by the different characteristics, adding the reinforcements in required compositions with the base metal [10]. Hence to overcome the limitations put forth by the conventional materials like higher weight, lowered physical and mechanical properties comparatively, composites are being preferred [2].

\subsection{Composite materials}

There is a massive technological upgradation in need and the industries are changing rapidly. Composites are the new age materials which are matching and fulfilling the current needs of the industries that are looking for an alternative to the conventional materials [1]. The composites are usually consisting of two or more distinct constituent material either physically or chemically which are arranged suitably or even in a distributed phase and matrix is a ceramic embedding a reinforcement phase.

The reinforcement phase is evenly distributed or embedded into the matrix phase [6]. The matrix is defined as a metal alloy in the productivity of the composite. When the matrix is a metal, the composite is termed metal matrix composites: a) metal matrix composites (MMCs) consist of at least two components, one is the metal matrix and the second component is reinforcement, b) if ceramic fibers are embedded in a matrix then they are called as ceramic matrix composites (CMCs). It can consist of any ceramic material, even carbon and carbon fibers can also be considered a ceramic material, c) if it consists 
a polymer resin as the matrix, with fibers as the reinforcement medium then it is a polymer-matrix composite (PMCs). These are used in several composite applications, even in the largest quantities [1].

\subsection{Aluminium matrix composites}

The aerospace and automotive industries are constantly researching for rapid development of metal matrix composites (MMC). Researchers are turning to particulate reinforced Aluminium metal matrix components (AMC) because of their relatively low cost and isotropic properties [2]. One constituent of aluminium alloy termed as matrix phase while the other constituent which is dispersed in matrix is reinforcement. Ceramic materials such as $\mathrm{SiC}, \mathrm{Al}_{2} \mathrm{O}_{3}$, $\mathrm{B}_{4} \mathrm{C}$, etc., are widely used as reinforcements. When compared to nonreinforced materials AMC gives better strength, improved stiffness, reduced density, improved high temperature properties, enhanced abrasion and wear resistance and better electrical performance [3].

\section{Al7075 Alloy}

Aluminium 7075 is an aluminium alloy, in which grades usually used in production of 7075-T6, 7075-T651. The chemical composition and properties of Al7075 is shown in Table no $1 \& 2$ respectively [6].

\section{Applications of AL7075 Alloy}

Typical applications for aluminium alloy 7075 include:

- aircraft and aerospace components,

- marine fittings,

- transport,

- bicycle frames,

- camera lenses,

- drive shafts,

- electrical fittings and connectors,

- brake components, Valves \& Couplings.

Tab. 1. Chemical composition of Al7075 alloy [6]

\begin{tabular}{ll}
\hline Material & Composition (wt $\%)$ \\
\hline Zinc & $6.012 \%$ \\
\hline Magnesium & $1.681 \%$ \\
\hline Copper & $1.812 \%$ \\
\hline $\begin{array}{l}\text { Silicon, Iron, Manganese, } \\
\text { Titanium, Chromium }\end{array}$ & Less than $0.5 \%$ \\
\hline
\end{tabular}

Tab. 2. Properties of A17075 alloy

\begin{tabular}{ll}
\hline Properties & Value \\
\hline Tensile strength & $83,000 \mathrm{psi}(572 \mathrm{MPa})$ \\
\hline Yield strength & $73,000 \mathrm{psi}(503 \mathrm{MPa})$ \\
\hline Elongation & $10-11 \%$ \\
\hline
\end{tabular}

Al7075 are often preferred in transport, marine, automotive and aviation applications, because of its high strength-to-weight ratio. The Al7075 has a greater strength and light weight are also desirable in other fields like rock climbing equipment, bicycle components, and hang glider airframes.

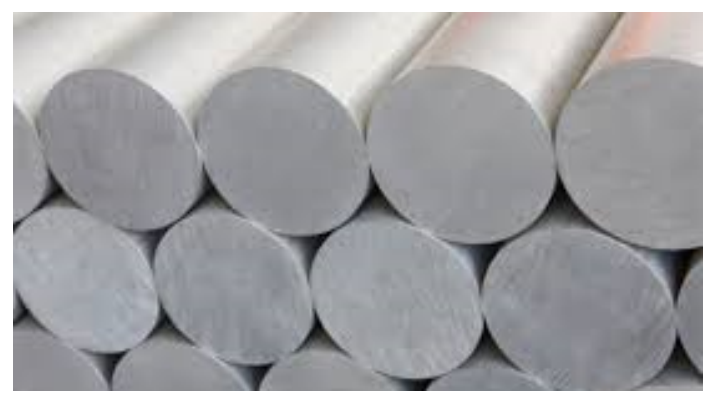

Fig. 1. AL7075 Alloy

\section{PROCESSING OF ALUMINIUM MATRIX COMPOSITES}

The processing for manufacturing of AMCs can be divided into two main groups [28, 1].

1. Liquid state process, it includes squeeze castings, stir casting, and ultrasonic assisted castings.

2. Solid state process, it includes powder blending followed by consolidation, friction stir process, high energy ball milling.

\subsection{Liquid state process}

Stir casting is a liquid state process, in which aluminium alloy is in matrix phase and ceramics are reinforcement phase. The aluminium alloy is heated and molten to liquid state and reinforcing phases which are mostly in powder form are distributed into molten aluminium alloy stirring mechanically. Squeeze casting is a combination of gravity die casting and closed die forging. Here, pressure is applied on the solidifying liquid metal. The following actions take place as a sequence of manufacturing: (i) pouring of measured quantity of liquid metal with adequate super heat in to the die cavity, (ii) applying pressure on the liquid metal and maintaining it till solidification is complete and (iii) removing the cast and preparation of the die for the next cycle. Ultrasonic assisted casting combines both solidification processes with ultrasonic cavitation-based dispersion of nano particles in metal [28].

\subsection{Solid state process}

The solid-state process is a powder metallurgy process and generally follows the given steps:

- manufacturing of powder,

- mixing and blending the powder,

- compacting,

- sintering. 


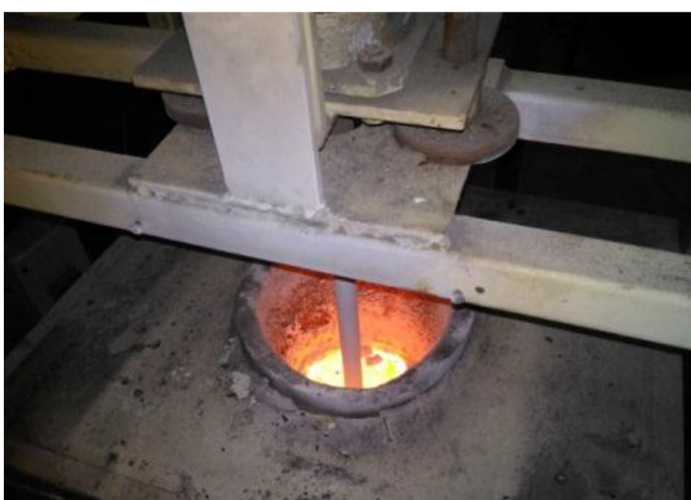

Fig. 2. Stir Casting Unit

Compacting is generally performed at room temperature. Sintering is usually conducted at atmospheric pressure. High energy ball milling is a simple method to produce aluminium matrix composites which incorporates flattering and welding, fracturing and rewelding of a mixture of powder particles in a high energy ball milling. Powder particles in the ball mill are subjected to high-energy collision, which eventually causes the powder particles to be cold-welded together and fractured. Friction stir processing produces deformation is by inserting a nonconsumable tool forcibly into the work piece, and revolving the tool in a stirring motion and pushed laterally through the work piece. This action mixes the material without changing the phase and creates a microstructure with fine, equiaxed grains [28].

\section{PROPERTIES OF ALUMINIUM COMPOSITE MATERIALS}

\subsection{Physical Properties}

Density is an important physical property. Since each element and compound have specific density associated with it to make it unique. Density is usually defined as the measure of the relative "heaviness" of objects with a constant volume. Density plays a very important role in the composite material study. These materials are used in space crafts and automotive industry and hence they must be of light weight. So, the density should be reduced by adding some reinforced material like $\mathrm{Al}_{2} \mathrm{O}_{3}, \mathrm{SiC}, \mathrm{B} 4 \mathrm{C}$, etc., in aluminium alloy. In a composite, the volume fraction is commonly used in property calculation. Density is also calculated by dividing the mass of specimen by the volume displaced by that specimen when both are in water. Also the temperature distribution and thermal properties of AMMCs are found to be superior at certain composition of addition of reinforcement particles [5]. Electrical conductivity of the AMMCs are also found to be improved on the addition of reinforcement particles thereby providing increased physical properties than normal non reinforced AL7075 material [30].

\subsection{Mechanical Properties}

Tensile strength, hardness, impact energy and fatigue strength are essentially functioning of the manufacturing process. Improving these mechanical properties as required is a major advantage which makes composite materials desirable resistance of a material to deformation, indentation, or penetration under abrasion, drilling, impact, scratching is known as hardness. Hardness is measured by hardness tests such as Brinell, Knoop, Rockwell, or Vickers. For metals like steel the hardness and tensile strength are empirically related. The ability of a material to withstand a pulling force acting on opposite directions which is making it to stretch and elongate is known as tensile strength. Force per cross-sectional area is its usual measurement unit. Fields like material science, mechanical engineering and structural engineering consider tensile strength properties highly. Comparatively AMCs are found to have more tensile and fatigue strength over conventional materials [3]. Materials like $\mathrm{Al}_{2} \mathrm{O}_{3}, \mathrm{SiC}, \mathrm{B}_{4} \mathrm{C}$, etc. are reinforced with AMCs, which significantly increase its elastic modulus, hardness and wear resistance [3].

\subsection{Tribological Properties}

The progressive loss of material due to relative motion between a surface and the contacting substance or substances is known as wear. These wear damages are usually in the form of micro-cracks or localized plastic deformation. Adhesive wear, abrasion wear, surface fatigue wear and corrosive wear are the types of wear possible [13]. The apparatus commonly used for measuring sliding friction and wear characteristics are Pin-on-Disc, Pin-on-Flat, Pin-on Cylinder, thrust washers, Pin-into-Bushing, Rectangular Flats on a Rotating Cylinder [13].

\section{REVIEW ON PROPERTIES OF COMPOSITE MATERIALS}

Krishnamoorthi and Balasubramanian reviewed that when the Al7075 is reinforced with various ceramic materials using the techniques such as stir, squeeze casting or ultrasonic casting, powder metallurgy, high energy ball milling and friction stir casting [1]. The properties of the matrix composite such as both mechanical and physical properties are varied and parameters such as reinforcement fraction, particle size and its behaviour during heat treatment and extrusion gets affected and yields significant goodness [1]. It is also mentioned that there is a significant drop in the density of the matrix composite, an increase in the hardness after reinforcement, increased elastic modulus and tensile strength over its base alloys. The wear rate has increased if applied load and speed are increased [1].

Prasad et al. have investigated by preparing a matrix composite reinforced with magnesium oxide 
using stir casting technique. They have varied the weight percentage of the particles at $5 \& 10$ have found that tensile properties and hardness and values after reinforcing have increased many-folds than nonreinforced nanoparticles [29]. Also, it is experimentally proven that stir casting was the best method for their fabrication as it resulted in even spreading of nanoparticles throughout the specimen. They experimentally found that at $100 \mathrm{wt} \%$ Aluminium alloy the ultimate load is $5.220 \mathrm{kN}$ \& Ultimate tensile strength is $50.887 \mathrm{~N} / \mathrm{mm}^{2}$, hardness value is 96.83 [29]. At $95 \mathrm{wt} \% \mathrm{Al}$ and $5 \mathrm{wt} \%$ of $\mathrm{MgO}$, Ultimate load is $13.500 \mathrm{kN}$, Ultimate tensile strength is $137.042 \mathrm{~N} / \mathrm{mm}^{2}$, and hardness value is 92.07 . At $90 \mathrm{wt} \%$ of $\mathrm{Al}$ and $10 \mathrm{wt} \%$ of $\mathrm{MgO}$ Ultimate load is $19.800 \mathrm{kN}$, Ultimate tensile strength is 197.211 N/mm², and hardness value is 100 [29].

Sambathkumar et al. suggests when reinforced with silicon carbide and titanium carbide using two steps stir casting method. This method proved that it has shown better hardness and tensile capabilities, higher density than base alloy [2]. It has also proved that there is increase in micro hardness if the volume of reinforcement is varied from 0 to $15 \mathrm{wt} \%$. Also increasing the particle size of reinforcement has increased its corrosion resistance in $3.5 \mathrm{wt} \%$ in $\mathrm{NaCl}$ solution proving better corrosion resistance than other aluminium alloys [2]. The photomicrographs, uniform distribution of reinforcement by two steps stir casting method is exhibited in their experimental investigation [2].

Devaneyan et al. has investigated and suggested that mixing $\mathrm{TiC}$ and $\mathrm{SiC}$ at different weight ratio based on has formulation of the design matrix using a statistical tool named response surface methodology (RSM) [3]. It is proved enhanced mechanical properties when $90 \mathrm{wt} \%$ of Al7075, $4 \mathrm{wt} \%$ of TiC, and $8 \mathrm{wt} \%$ of SiC composition. The coefficient of friction appears to be more which has been obtained by ring compression test [3]. Based on the experiments and tests conducted, it is seen that micro hardness of up-to $52.12 \mathrm{HV}$ is obtained with $90 \mathrm{wt} \%$ of Al7075, $4 \mathrm{wt} \%$ of $\mathrm{SiC}$, and $8 \mathrm{wt} \%$ of TiC. The ring compression test also lime lights specimen with $90 \mathrm{wt} \%$ of Al7075, $4 \mathrm{wt} \%$ of $\mathrm{SiC}$, and $4 \mathrm{wt} \% \mathrm{TiC}$ of density has lowest coefficient of friction compared to other samples [3]. Also, their investigation clearly shows that addition of $\mathrm{SiC}$ and $\mathrm{TiC}$ increases the wear resistance of the composites [3].

Ravi investigated mechanical properties such as yield, tensile strength and brinell hardness of composites. It has significantly been enhanced with a drop in impact strength for this particular combination of reinforcement [4]. In his experiment, for the following composition of Al7075-5 wt\% $\mathrm{TiC}+5 \mathrm{wt} \% \mathrm{SiC}$. MMCs hardness is increased by and 39\% when compared with A17075 base alloy. An improvement of $32 \%$ when compared with as-cast
Al7075 base alloy is witnessed. If Al7075- $5 \mathrm{wt} \%$ $\mathrm{TiC}+5 \mathrm{wt} \% \mathrm{SiC}$ is the composition and its ultimate tensile strength being 129 and $155 \mathrm{MPa}$ respectively. Al7075-5 wt \% $\mathrm{TiC}+5 \mathrm{wt} \% \mathrm{SiC}$ provides yield strength of 104 and $116 \mathrm{MPa}$ respectively [4]. Therefore, composites containing $5 \mathrm{wt} \%$ Titanium carbide and $5 \mathrm{wt} \%$ silicon carbide reinforcements are seen to show off superior mechanical properties from his experimental research work [4].

Jacob et al. fabricated by stir casting process has experimented on stirring time, temperature of the melt and blade angle. High strength particulates strengthened the metal matrix composite without causing much disturbance to ductility by stir casting process [5]. Fabricated specimen was analysed using laser flash analysis (LFA) and its thermal conductivity was determined and other changes in microstructure were determined using SEM analysis [5]. It is concluded that experimental study of tensile strength $69.519 \mathrm{~N} / \mathrm{mm}^{2}$ is obtained when $10 \mathrm{wt} \%$ reinforcement is done using aluminium oxide [5]. Micro hardness value is $148.09 \mathrm{VHN}$ obtained when $10 \mathrm{wt} \%$ reinforcement of aluminium oxide. Thermal conductivity is higher at $10 \mathrm{wt} \%$ reinforcements. Also, temperature distribution and thermal flux are outstanding when $10 \mathrm{wt} \%$ reinforcement of $\mathrm{Al}_{2} \mathrm{O}_{3}$ in the Al7075 matrix.

Subramaniam et al. experimentally suggested that hardness has increased by $33 \%$ when addition of $9 \mathrm{wt} \%$ of $\mathrm{B}_{4} \mathrm{C}$ and $3 \mathrm{wt} \%$ of CSFA [6]. The tensile strength is increased by $66 \%$ when $9 \mathrm{wt} \% \mathrm{~B}_{4} \mathrm{C}$ and $3 \mathrm{wt} \%$ of CSFA are added as reinforcement to Al7075 alloy. If the abovementioned values are exceeded, it has been found that there is a drop in the tensile strength and hardness. Homogenous distribution of reinforcement particles is ensured by screening using optical micrographs [6]. Hardness increases with increasing reinforcement content in the matrix. The reinforcement particles act as a barrier to cracks and resists fracture better than non-reinforced Al7075. The microstructure also provides with minimum level of porosity and uniform distribution of reinforcement particles up to $9 \mathrm{wt} \% \quad \mathrm{~B}_{4} \mathrm{C}$ and $3 \mathrm{wt} \%$ CSFA composites.

Shrivastaval et al. investigated on the tribological properties of silicon carbide-based aluminium metal network composite and aluminium lattice compound have been read for different sliding velocities of 3.14 and $3.77 \mathrm{~m} / \mathrm{s}$ and load extend from 10 to $30 \mathrm{~N}$ under dry, greased up, and idle gas (argon) condition [13]. Nail to circle tribometer were utilized for tests. The composite was manufactured by mix throwing course by utilizing A17075 compound as the network and $10 \%$ by weight silicon carbide as strengthened material. The estimation of coefficient of erosion is seen as most extreme if there should be an occurrence of latent condition in framework amalgam at sliding 
speed $3.77 \mathrm{~m} / \mathrm{s}$ and least if there should be an occurrence of greased up condition in composite at sliding rate $3.14 \mathrm{~m} / \mathrm{s}$ [13]. Wear rate increments with the typical burden and sliding rate and it is most extreme in latent state of framework amalgam at $30 \mathrm{~N}$.

Raju et al. made an examination on Aluminium metal network composites are raising as promising materials in the field of light weight vehicles, aviation, electrical, space transports and car for their different applications and specialized equipments [12]. Aluminium based metal network composite was effectively thrown by mix throwing process for the three scopes of fly debris particles from 15\%,20\% and $25 \%$ weight. The expansion of the fortification causes decrease in elasticity and increment in the hardness [12]. In the test with support of $20 \mathrm{wt} \%$ fly debris delineates the uniform dissemination of the particles and gives great hardness of the AMMC. The malleable trait of the AMMC decline with a lower rate however the weight proportion of the material abatement prominently which is brilliant sign for the light weight material [12].

Suryakumari et al. made a study in these mechanical properties of the created aluminium 7075 half and half metal lattice composites fortified with different weight $\%$ of $\mathrm{SiC}$ and $\mathrm{Al}_{2} \mathrm{O}_{3}$ particulates by mix throwing strategy the mechanical properties like Brinell hardness, Rockwell hardness were tested [14]. The high hardness esteem acquired with the expansion of $2.5 \mathrm{wt} \%$ of $\mathrm{Al}_{2} \mathrm{O}_{3}$ and $5 \mathrm{wt} \%$ of $\mathrm{SiC}$. The effect quality of the half and half MMC has expanded with high weight level of $\mathrm{Al}_{2} \mathrm{O}_{3}$ and $\mathrm{Sic}$ [14]. The high effect quality worth got with the expansion of $7.5 \mathrm{wt} \%$ of $\mathrm{Al}_{2} \mathrm{O}_{3}$ and $5 \mathrm{wt} \%$ of $\mathrm{SiC}$. The expansion of earthenware particles like $\mathrm{Al}_{2} \mathrm{O}_{3}$ and $\mathrm{SiC}$ brings about increments in the hardness and sway quality of the crossover MMCs [14].

Uvaraja et al. investigated the impact of two hard stage support particulates silicon carbide and a steady weight level of boron carbide on tribological conduct of Al7075 composites. The weight rates of silicon carbide particulate considered here are 5\%,10\%, and $15 \%$ though for boron carbide a steady $3 \%$ weight is utilized all through the examination [8]. Aluminium amalgam as base lattice is fortified with a blend of two sorts of particulates alongside magnesium $(\mathrm{Mg}) 1 \%$ as restricting component. The heat treatment process exposing to solutioning treatment at a temperature of $530^{\circ} \mathrm{C}$ for $1 \mathrm{~h}$ followed by extinguishing in water. The wear surface morphology and wear system of the pins is researched utilizing examining electron magnifying lens (SEM). Heat treatment is a huge impact on miniaturized scale hardness of Al 7075 framework compound and its composites. The treated composite with $15 \mathrm{wt} \% \mathrm{SiC}$ portrays high hardness estimation of 160 to $199 \mathrm{VHN}$ [8]. The harder $\mathrm{SiC}$ and $\mathrm{B}_{4} \mathrm{C}$ particles contribute essentially to the improved wear opposition. It decreases of $27.27 \%$ and $54.03 \%$ in rubbing coproductive and wear rates individually for composites containing $15 \mathrm{wt} \% \mathrm{SiC}$ when contrasted with the framework combination is studied [8].

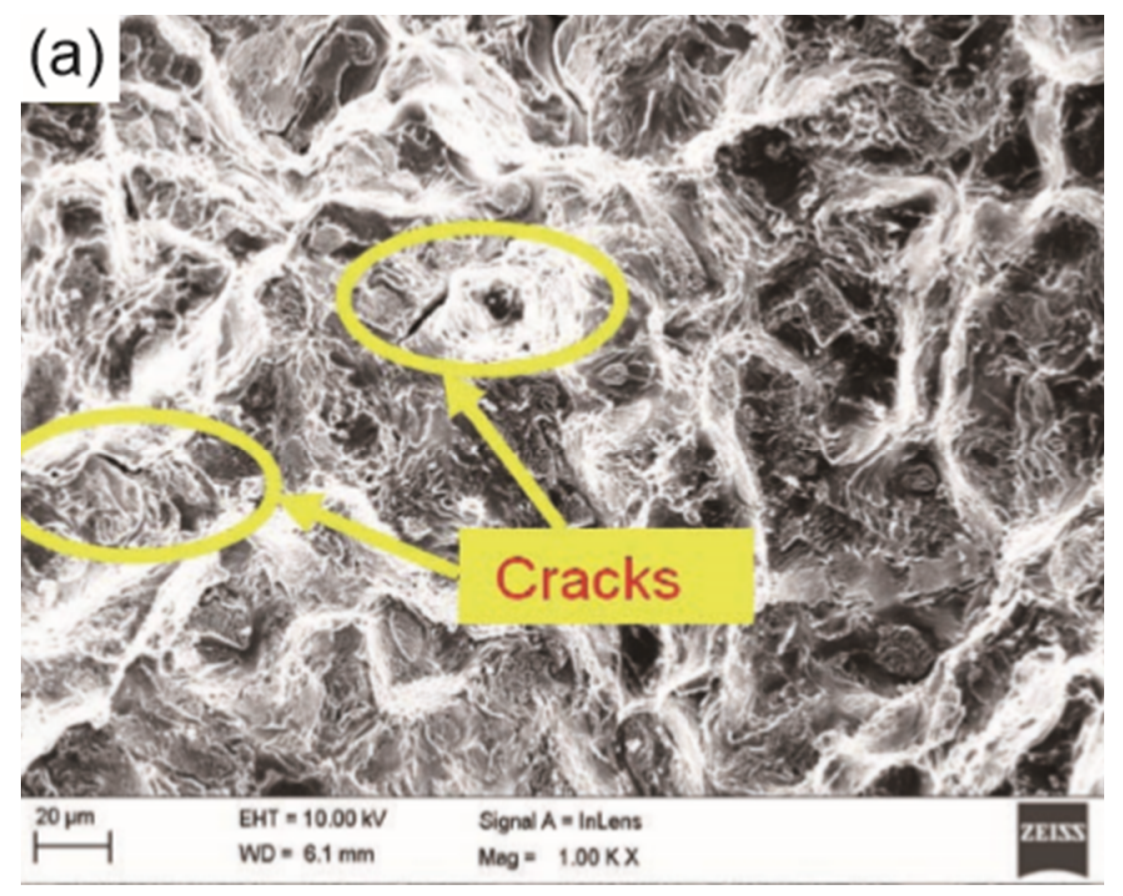

Fig. 3. SEM micrography of $\mathrm{B}_{4} \mathrm{C}$ reinforced $\mathrm{AL} 7075$ depicting cracks from [6] 


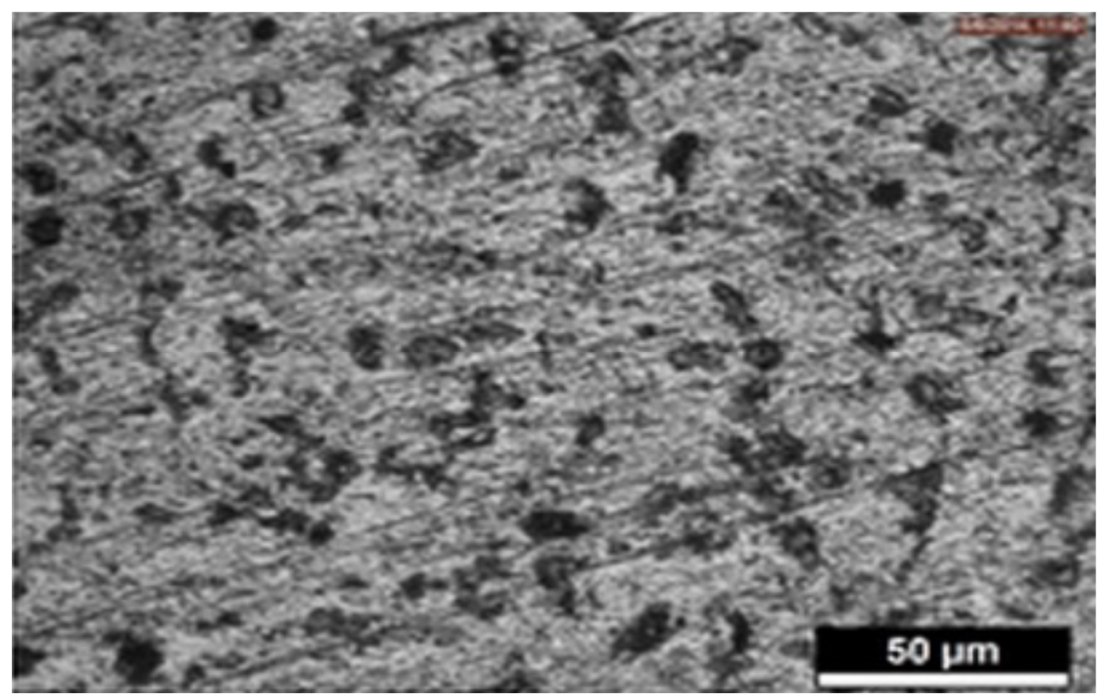

Fig. 4. Optical Microphotograph of reinforced AL7075 alloy

Raghavendra et al investigated that in this work hybrid metal matrix composite have been created utilizing mix throwing process for improving the wear behaviour at lower cost. The silicon carbide $(\mathrm{SiC})$ as one of the fortifications utilized with $3 \%$ weight part and Alumina $\left(\mathrm{Al}_{2} \mathrm{O}_{3}\right)$ as the significant fortification in $3 \%, 6 \%, 9 \%$ \& $12 \%$ weight division. Al7075 has been considered as the network material [18]. The ease mix throwing process has been utilized for the advancement of the composite system. The nail to plate wear test has been continued every one of the examples at different rates of 300, 600, 900 and 1200 rpm, differing heap of $1 \mathrm{~kg}, 2 \mathrm{~kg}, 3 \mathrm{~kg}$ and $4 \mathrm{~kg}$ and fluctuating sliding separations of $1 \mathrm{~km}, 2 \mathrm{~km}, 3 \mathrm{~km}$ and $4 \mathrm{~km}$. These tests uncover that the wear obstruction increments with the expansion in the fortification weight portion [18]. By mix throwing process the crossover metal lattice composite can be grown adequately. Uniform conveyance of the particulate and isotropic property of the composite can be acquired my soften temperature of $750^{\circ} \mathrm{C}$ and blending by the alumina stirrer until pouring the soften. The thickness of the composite material is half of the regular material and it increments with expansion of artistic material [18].

Pugalenthi et al has said that aluminium metallattice composites are broadly delivered with various earthenware mixes as fortifications to improve their properties and to suit different auxiliary applications [24]. The present work includes the manufacture of Al7075 composites with silicon carbide $(\mathrm{SiC})$ and aluminium oxide (Al2O3) as fortifications through mix throwing [24]. Four examples were delivered with various syntheses including $\mathrm{SiC}(3,5,7$ and $9 \mathrm{wt} \%)$ and $\mathrm{Al} 2 \mathrm{O} 32 \mathrm{wt} \%$ in every one of the mixes. Mechanical properties like extreme elasticity (UTS), yield quality (YS), level of stretching (\% of extension) and hardness (VHN) were analysed, alongside fractography considers [24]. The test outcomes uncovered that the expansion in the wt $\%$ parts of the fortification materials caused an expansion in the elasticity, yield quality and hardness of the aluminium composite, aside from the $\%$ of extension, which is diminished with the expansion of clay particles. SiC and $\mathrm{Al} 2 \mathrm{O} 3$ particles of 30/40 microns are included to the liquid A17075 alongside magnesium powder.

Das et al. investigated the silicon carbide particulate (SiCp) with Al7075 metal matrix composites (MMCs) were manufactured utilizing fluid metallurgy mix throwing process. Mean molecule size and weight level of the support were changed by Taguchi L9 Design of Tests (DOE) [23]. One lot of the cast composites were then warmth treated to T6 condition. Optical micrographs of the MMCs uncover reliable scattering of fortifications in the network stage. Mechanical properties were resolved for both as-cast and warmth treated MMCs for examination of the exploratory outcomes [23]. The process parameters were improved utilizing Taguchi based dark social examination for the different mechanical properties of the warmth treated MMCs. The biggest estimation of mean dim social evaluation was acquired for the composite with mean molecule size $6.18 \mu \mathrm{m}$ and 25 weight $\%$ of support. Steady scattering of $\mathrm{SiC}$ particulates in the framework amalgam was seen in the optical micrographs of $\mathrm{Al} 7075 / \mathrm{SiCp}$ MMCs. T6 state of warmth treatment improved all the mechanical properties [23]. The biggest estimation of the mean dark social evaluation was accomplished for the MMC with mean molecule size $6.18 \mu \mathrm{m}$ and 25 weight $\%$ of $\mathrm{SiCp}$ fortification. It is the suggested mix of levels of creation process parameters for $\mathrm{Al} 7075 / \mathrm{SiCp}$ MMCs. ANOVA results for dark social evaluation show that mean molecule size of $\mathrm{SiC}$ is the more affecting procedure parameter than its weight $\%$ in the MMCs. 


\section{TABULATION OF RESULTS}

The following tabulation is done to give a brief insight about the review done about the various researches done on AL $7075 \mathrm{MMCs}$ to give the upcoming researches the knowledge collectively at one place. Also the tabulation makes it easier to find the results of researches done by various researchers whose works are reviewed above to easily compare and know the final results at a glance so that they can get a clear view of the results obtained from various compositions and processes and can work based on that.

Tab. 3. Details of combinations used, manufacturing process and their result

\begin{tabular}{|c|c|c|c|}
\hline S.NO & MATERIAL & $\begin{array}{l}\text { MANUFACTURING } \\
\text { PROCESS }\end{array}$ & RESULT \\
\hline 1 & $\begin{array}{l}\text { Al7075 Is Reinforced with } \\
\text { Various Ceramic Materials [1] } \\
\text { (general review). }\end{array}$ & $\begin{array}{l}\text { Stir, Squeeze Casting } \\
\text { or Ultrasonic Casting, } \\
\text { Powder Metallurgy, } \\
\text { High Energy Ball } \\
\text { Milling and Friction } \\
\text { Stir Casting } \\
\end{array}$ & $\begin{array}{l}\text { The density is decreased with reinforcement into the matrix } \\
\text { material. The Wear rate of composites increases with } \\
\text { increasing applied load and speed and Highest wear rate is } \\
\text { obtained for the lower particle size. }\end{array}$ \\
\hline 2 & $\begin{array}{l}\text { Al7075 With Magnesium Oxide } \\
\text { Nano powder }(5,10 \mathrm{wt} \%) \text { [29] }\end{array}$ & Stir Casting Technique & $\begin{array}{c}\text { At } 95 \mathrm{wt} \% \text { of } \mathrm{Al} \text { and } 5 \mathrm{wt} \% \text { Of Mgo, } \\
\text { Ultimate Load }=13.500 \mathrm{kN} \text {, Ultimate Tensile } \\
\text { Strength }=137.042 \mathrm{~N} / \mathrm{mm}^{2}, \text { Hardness Value }=92.07 \\
\text { At } 90 \mathrm{wt} \% \mathrm{Al} \text { and } 10 \mathrm{wt} \% \mathrm{Mgo} \text { Ultimate Load }=19.800 \mathrm{kN} \text {, } \\
\text { Ultimate Tensile Strength }=197.211 \mathrm{~N} / \mathrm{mm}^{2} \\
\text { Hardness Value }=100(\mathrm{VHN})\end{array}$ \\
\hline 3 & $\begin{array}{l}\text { A17075 - Tic and Sic } \\
\text { (Varying From 0-15 wt \%) [2] }\end{array}$ & Stir Casting Technique & $\begin{array}{c}\text { Ultimate Tensile Strength }=240 \text { MPa Corrosion Resistance } \\
\text { In } 3.5 \mathrm{wt} \% \text { in Nacl Solution Proving Better Corrosion } \\
\text { Resistance (Tested using SEM) }\end{array}$ \\
\hline 4 & $\begin{array}{c}\text { AL7075 - TiC and } \mathrm{SiC} \\
(90 \mathrm{wt} \% \text { of } \mathrm{Al} 7075,4 \mathrm{wt} \% \text { of } \mathrm{TiC}, \\
\text { and } 8 \mathrm{wt} \% \text { of } \mathrm{SiC})[3]\end{array}$ & Stir Casting Technique & $\begin{array}{c}\text { Micro hardness }=52.12 \mathrm{HV} \text {. The compression test reveals } \\
\text { that its density has lowest coefficient of friction }\end{array}$ \\
\hline 5 & $\begin{array}{c}\text { Al7075 With Tic And Sic } \\
\text { (Al7075-5 wt } \% \text { TiC+5 wt } \% \mathrm{SiC})[4]\end{array}$ & Stir Casting Technique & $\begin{array}{c}\text { Hardness Increased By } 39 \% \text {, ultimate tensile strength }=155 \mathrm{MPa} \text {, } \\
\text { yield strength }=116 \mathrm{MPa}\end{array}$ \\
\hline 6 & $\begin{array}{l}\text { Al7075 With Aluminium Oxide } \\
\left(5 \%, 10 \%, 15 \% \text { Of } \mathrm{Al}_{2} \mathrm{O}_{3}\right)[5]\end{array}$ & Stir Casting Technique & $\begin{array}{c}\text { Tensile Strength }=69.519 \mathrm{~N} / \mathrm{mm}^{2}, \text { Micro Hardness }=148.09 \\
\text { (VHN) In SEM Analysis Thermal Conductivity Is Higher; } \\
\text { Temperature Distribution and Thermal Flux Are } \\
\text { Outstanding at } 10 \mathrm{wt} \% \text { Reinforcement. }\end{array}$ \\
\hline 7 & $\begin{array}{l}\text { Al7075-Boron Carbide-Coconut } \\
\text { Shell Fly Ash } \\
\left(0,3,6,9,12 \text { wt } \% \mathrm{~B}_{4} \mathrm{C}\right) \\
\text { (3wt \% CSFA) [6] }\end{array}$ & Stir Casting Technique & $\begin{array}{c}\text { In } 9 \text { wt } \% \text { Of } \mathrm{B}_{4} \mathrm{C}+3 \mathrm{wt} \% \text { Of CSFA The Hardness Has } \\
\text { Increased By 33\%. The Tensile Strength Is Increased By } \\
66 \% \text { The Microstructure Also Provides with Minimum } \\
\text { Level of Porosity and Uniform Distribution of } \\
\text { Reinforcement Particles. }\end{array}$ \\
\hline 8 & Al7075 - Sic (10 wt\%) [13] & Stir Casting Technique & $\begin{array}{l}\text { Sliding speed }=3.77 \mathrm{~m} / \mathrm{s} \text { (ungreased up condition). Sliding } \\
\text { speed }=3.14 \mathrm{~m} / \mathrm{s} \text { (greased up condition). Wear rate } \\
\text { increments with the typical burden and sliding rate and it is } \\
\text { most extreme in latent state of framework amalgam at } 30 \mathrm{~N} \text {. }\end{array}$ \\
\hline 9 & $\begin{array}{l}\text { Al7075-T6 with FLY ASH } \\
\quad(15,20,25 w t \%)[12]\end{array}$ & Stir Casting Technique & $\begin{array}{l}\text { The SEM images revel that the distribution of the } \\
\text { reinforcement fly ash is uniform. The reinforcement of } 20 \% \\
\text { fly ash gives good hardness Highest Hardness value }=80(\mathrm{BHN})\end{array}$ \\
\hline 10 & $\begin{array}{c}\mathrm{A} 17075-\mathrm{Sic}-\mathrm{Al}_{2} \mathrm{O}_{3} \\
(2.5,5,7.5 \mathrm{wt} \% \text { OF DIFFERENT } \\
\text { COMPOSITIONS OF SIC AND } \\
\mathrm{Al}_{2} \mathrm{O}_{3)}[14]\end{array}$ & Stir Casting Technique & $\begin{array}{c}\text { The highest hardness value }=130(\mathrm{BHN}) . \text { Highest impact } \\
\text { value }=10 \mathrm{~J} .\end{array}$ \\
\hline 11 & $\begin{array}{l}\text { Al7075 - Sic }(5,10,15 w t \%)- \\
\text { Magnesium }(1 \mathrm{wt} \%)[8]\end{array}$ & Stir Casting Technique & $\begin{array}{l}\text { Hardness value }=199(\mathrm{VHN}) \text {. A Maximum reduction of } \\
27.27 \% \text { and } 54.03 \% \text { in friction co-efficient and wear rate. }\end{array}$ \\
\hline 12 & $\begin{array}{l}\mathrm{Al} 7075-\mathrm{Sic}(3 \mathrm{wt} \%)-\mathrm{Al}_{2} \mathrm{O}_{3} \\
\quad(3,6,9,12 \mathrm{wt} \%)[18]\end{array}$ & Stir Casting Technique & $\begin{array}{c}\text { Microstructure analysis reveals uniform Distribution. } \\
\text { Al7075+12\% } \mathrm{Al} 2 \mathrm{O} 3+3 \% \mathrm{SiC} \text { Density }=2752 \mathrm{Kg} / \mathrm{m}^{3}, \text { Micro } \\
\text { Hardness }=147.51300 \mathrm{gmf} / 13 \mathrm{Sec}, \text { Wear }=71 \mathrm{micron} \text {, Wear } \\
\text { Rate }=1.26910^{-4} \mathrm{~mm}^{3} / \mathrm{N} \mathrm{m}, \text { Coefficient of friction }=0.3076\end{array}$ \\
\hline 13 & $\begin{array}{c}\mathrm{Al} 7075-\mathrm{SIC}(3,5,7,9 \mathrm{wt} \%) \\
\mathrm{Al}_{2} \mathrm{O}_{3}(2 \mathrm{wt} \%)[24]\end{array}$ & Stir Casting Technique & $\begin{array}{l}\text { The microstructures show the reinforcing particles in the } \\
\text { matrix and the solidification pattern. Al7075+9 wt } \% \text { of } \\
\mathrm{SiC}+2 \mathrm{wt} \% \text { of } \mathrm{A} 12 \mathrm{O} 3 \text { has highest value HARDNESS }=119 \mathrm{VHN} \text {, } \\
\text { UTS }=325 \mathrm{MPa} \text { and elongation of } 2.08 \text {. }\end{array}$ \\
\hline 14 & $\begin{array}{l}\text { Al7075- sic (size } 6.18 \mu \mathrm{m} \text { and } \\
25 \mathrm{wt} \%)[23]\end{array}$ & Stir Casting Technique & $\begin{array}{l}\text { Consistent dispersion of } \mathrm{SiC} \text { particulates in the matrix alloy } \\
\text { was observed in the optical micrographs. Around } 42 \% \text { of } \\
\text { improvement in grey relational grade has been achieved. }\end{array}$ \\
\hline
\end{tabular}




\section{CONCLUSIONS}

This review provides the experimental and theoretical findings of research work. It helpful for other researchers to get an overview about the advances made in the research process on coming up with Al7075 MMCs that are desired by industries to replace the conventional materials which are currently being used.

1. It is evident that there is a drop in density of the Al7075 composites when ceramics are reinforced into the matrix material.

2. The review shows that significant increase in the hardness of the metal matrix composite. Further improvement of hardness can be done by heat treatment, temperature ageing process

3. This type of AMC is found to have higher elastic modulus and tensile strength when compared to base alloys which are being used currently by industries.

4. It is clear that wear rate of composites is increased when applied load and speed are increased. It is also observed that lowering particle size helps us to achieve uniform mixing in the hybrid composites.

5. It is found to have high elastic modulus and tensile strength over the base alloys.

Also, it is found that, to make up the density drop caused by adding ceramics as reinforcement with AL-7075, agro-wastes like coconut shell fly ash, bean pod ash, rise husk and palm oil ash.

\section{References}

1. Krishnamoorthi, K. and Balasubramanian, P., 2015. Review the Properties of Al7075 Matrix Composites. J. Mater. Sci. Mech. Eng., 2(1), pp.85-90

2. Sambathkumar, M., Navaneethakrishnan, P., Ponappa, K.S.K.S. and Sasikumar, K.S.K., 2017. Mechanical and corrosion behavior of Al7075 (hybrid) metal matrix composites by two steps stir casting process. Latin american journal of solids and structures, 14(2), pp.243-255.

3. Pradeep Devaneyan, S., Ganesh, R. and Senthilvelan, T., 2017. On the mechanical properties of hybrid aluminium 7075 matrix composite material reinforced with $\mathrm{SiC}$ and TiC produced by powder metallurgy method. Indian Journal of Materials Science, 2017

4. Ravi B., 2017. Fabrication and mechanical properties of Al7075-SiC-TiC hybrid metal matrix composites. International Journal of Engineering Science Invention, 6, pp. 12-9

5. Jacob, S., Shajin, S. and Gnanavel, C., 2017, March Thermal analysis on A17075/A12O3 metal matrix composites fabricated by stir casting process. In IOP Conference Series: Materials Science and Engineering (Vol. 183, No. 1, p. 012010). IOP Publishing

6. Subramaniam, B., Natarajan, B., Kaliyaperumal, B. and Chelladurai, S.J.S., 2018. Investigation on mechanical properties of aluminium 7075-boron carbide-coconut shell fly ash reinforced hybrid metal matrix composites. China Foundry, 15(6), pp. 449-456

7. Rajendra.S.K. and Ramesha.C.M., 2015. "A Survey of A17075 Aluminium Metal Matrix Composites"
International Journal of Science and Research. 4(2), pp. 10711075

8. Uvaraja, V.C., Natarajan, N., Sivakumar, K., Jegadheeshwaran, S. and Sudhakar, S., 2015. Tribological behavior of heat-treated Al 7075 aluminium metal matrix composites

9. Dasgupta, R., 2012. Aluminium alloy-based metal matrix composites: a potential material for wear resistant applications. ISRN metallurgy, 2012

10. Saravanan, C., Subramanian, K., Krishnan, V.A. and Narayanan, R.S., 2015. Effect of particulate reinforced aluminium metal matrix composite-a review. Mechanics and Mechanical Engineering, 19(1), pp.23-30

11. Balasubramani, S. and Balaji, N., 2016. Investigations of vision inspection method for surface defects in image processing techniques-a review. Advances in Natural and Applied Sciences, 10(6 SE), pp.115-120

12. Raju, F.A. and Kumar, M.D., 2017. Micro Structure and Mechanical Behavior of AL7075-T6 and Fly Ash Metal Matrix Composite Produced by Stir Casting Process. International Journal of Theoretical and Applied Mechanics, 12(2), pp.365374

13. Shrivastava, A.K., Singh, K.K. and Dixit, A.R., 2018. Tribological properties of Al 7075 alloy and Al 7075 metal matrix composite reinforced with $\mathrm{SiC}$, sliding under dry, oil lubricated, and inert gas environments. Proceedings of the Institution of Mechanical Engineers, Part J: Journal of Engineering Tribology, 232(6), pp.693-698

14. Suryakumari, T.S.A., Ranganathan, S. and Shankar, P., 2015. Study on Mechanical Properties of Al 7075 Hybrid Metal Matrix Composites. In Applied Mechanics and Materials (Vol. 813, pp. 230-234). Trans Tech Publications Ltd

15. Balaji, N., Balasubramani, S., Ramakrishnan, T. and Sureshbabu, Y., 2020. Experimental Investigation of Chemical and Tensile Properties of Sansevieria Cylindrica Fiber Composites. In Materials Science Forum (Vol. 979, pp. 58-62). Trans Tech Publications Ltd

16. Dileep, B.P., Vitala, H.R., Megalingam, A. and Karthik, K., 2018. Mechanical and tribological characterization nitrided Al-7075/A12O3 metal matrix composites. Periodicals of Engineering and Natural Sciences, 6(2), pp. 64-70

17. Vinitha, B.S., 2014. Motgi, Evaluation of Mechanical Properties of Al 7075 Alloy, Flyash, SiC and Red mud Reinforced Metal Matrix composites, Inter. J. Sci. Research. Develop, 2, pp.190-193

18. Raghavendra, N. and Ramamurthy, V.S., 2015. Tribological Characterization of AL7075/AL203/SIC Reinforced Hybrid Particulate Metal Matrix Composite Developed by Stir Casting Process. International Journal of Recent advances in Mechanical Engineering (IJMECH), 4

19. Rao, P.C.S., Prasad, T. and Harish, M., 2017. Evaluation of Mechanical Properties of A17075-ZrO2 Metal Matrix Composite by using Stir Casting

20. Technique. International Journal of Scientific Research Engineering \& Technology, 6(4), pp.2278-0882

21. Subramaniam, B., Natarajan, B., Kaliyaperumal, B. and Chelladurai, S.J.S., 2019. Wear behaviour of aluminium 7075-boron carbide-coconut shell fly ash reinforced hybrid metal matrix composites. Materials Research Express, 6(10), p.1065d3

22. Kumar, G.V., Rao, C.S.P., Selvaraj, N. and Bhagyashekar, M.S., 2010. Studies on Al6061-SiC and Al7075-A12O3 metal matrix composites. Journal of Minerals \& Materials Characterization \& Engineering, 9(1), pp.43-55

23. Bhat, A. and Kakandikar, G., 2019. Manufacture of silicon carbide reinforced aluminium 6061 metal matrix 
composites for enhanced sliding wear properties. Manufacturing Review, 6, p.24

24. Das, D., Mishra, P., Chaubey, A. and Singh, S., 2016. Fabrication process optimization for improved mechanical properties of Al 7075/SiCp metal matrix composites. Management Science Letters, 6(4), pp.297-308

25. Pugalenthi, P. \& M., JAYARAMAN \& Subburam, Venkatajalapathy. (2019). Study of the microstructures and mechanical properties of aluminium hybrid composites with $\mathrm{SiC}$ and $\mathrm{Al} 2 \mathrm{O} 3$. Materiali in tehnologije. 53. 49-55

26. Subramaniam, Balasubramani \& Dhanabalakrishnan, K.P. \& Balaji N. (2015). Optimization of machining parameters in aluminium HMMC using response surface methodology. International Journal of Applied Engineering Research. 10. 19736-19739

27. Sureshbabu, Y., Ashokavarthnan, P., Balasubramani, S. and Naveenprabhu, V., 2019, October. Experimental investigation on four strokes catalytic coated spark ignition (SI) engine. In AIP Conference Proceedings (Vol. 2161, No. 1, p. 020041). AIP Publishing LLC

28. Venkatesh, S., Balasubramani, S., Venkatramanan, S. and Gokulraj, L., Standardization of hpx spool for lead time reduction of string test. Journal of Mechanical and Civil Engineering, 2(6), pp.62-79

29. Saravanan S, Senthil Kumar P, Ravichandran M, Anandhakrishnan V and Balan A V., 2017, Processing of aluminium metal matrix composites - A review", Journal of Manufacturing Engineering,12(3), pp 130-141

30. T. Prasad, P. Chinna Sreenivas Rao, B. Vijay Kiran, Investigation of Mechanical Properties of $\mathrm{Al} 7075$ with Magnesium oxide Nano Powder Mmc, IOSR Journal of Mechanical and Civil Engineering (IOSR-JMCE), pp. 60-65

31. Ajay Singh, Love Kumar, Mohit Chaudhary, Om Narayan, Pallav Sharma, Piyush Singh, Bhaskar Chandra Kandpal, Som Ashutosh, 2013, Manufacturing of AMMCS using stir casting process and testing its mechanical properties, International Journal of Advanced Engineering Technology, pp 26-29

\section{Biographical notes}

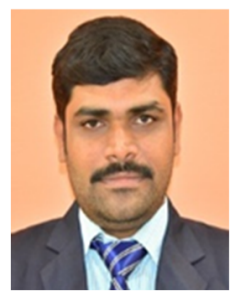

Balasubramani Subramaniam, male born in 1984, working as an Assistant Professor in Sri Eshwar College of Engineering, Tamilnadu, India. His research interests mainly focus on the manufacturing and testing of metal matrix composites, published more than 10 scientific papers in international and national journals.

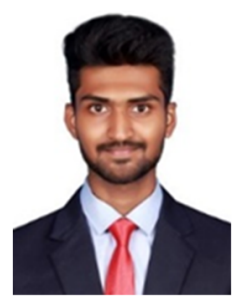

Vijay Rengaraj Purusothaman, male born in 1998, currently pursuing B.E in Mechanical Engineering in Sri Eshwar College of Engineering, Coimbatore 2016-2020. This review journal is part of his final year project on experimental investigation $\mathrm{On} \mathrm{AL}$ 7075 AMMCs.

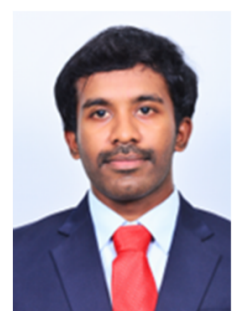

Sibi Mayuran Karuppusamy, male born in 1998, currently pursuing B.E in Mechanical Engineering in Sri Eshwar College of Engineering, Coimbatore 2016-2020. This review journal is part of his final year project on experimental investigation $\mathrm{On} \mathrm{AL}$ 7075 AMMCs.

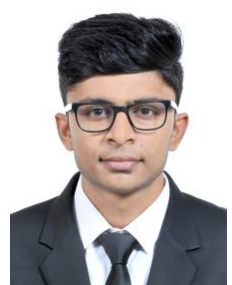

Shree Hari Ganesh, male born in 1998, currently pursuing B.E in Mechanical Engineering in Sri Eshwar College of Engineering, Coimbatore 2016-2020. This review journal is part of his final year project on experimental investigation $\mathrm{On} \mathrm{AL}$ 7075 AMMCs.

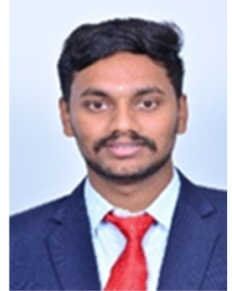

Raj Kumar Markandan, male born in 1998, currently pursuing B.E in Mechanical Engineering in Sri Eshwar College of Engineering, Coimbatore 2016-2020. This review journal is part of his final year project on experimental investigation $\mathrm{On} \mathrm{AL}$ 7075 AMMCs. 
